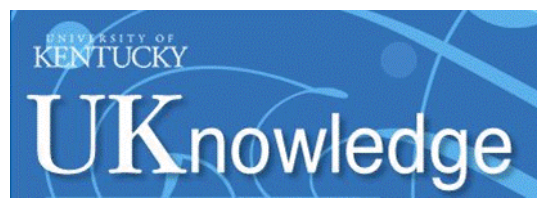

University of Kentucky

UKnowledge

Pharmacology and Nutritional Sciences Faculty

Publications

Pharmacology and Nutritional Sciences

$3-2020$

\title{
Amylin as a Potential Link between Type 2 Diabetes and Alzheimer Disease
}

\author{
Florin Despa \\ University of Kentucky, f.despa@uky.edu \\ Larry B. Goldstein \\ University of Kentucky, larry.goldstein@uky.edu \\ Geert Jan Biessels \\ University Medical Center Utrecht, the Netherlands
}

Follow this and additional works at: https://uknowledge.uky.edu/pharmacol_facpub

Part of the Neurology Commons, and the Pharmacology, Toxicology and Environmental Health

Commons

Right click to open a feedback form in a new tab to let us know how this document benefits you.

\section{Repository Citation}

Despa, Florin; Goldstein, Larry B.; and Biessels, Geert Jan, "Amylin as a Potential Link between Type 2 Diabetes and Alzheimer Disease" (2020). Pharmacology and Nutritional Sciences Faculty Publications. 104.

https://uknowledge.uky.edu/pharmacol_facpub/104

This Letter to the Editor is brought to you for free and open access by the Pharmacology and Nutritional Sciences at UKnowledge. It has been accepted for inclusion in Pharmacology and Nutritional Sciences Faculty Publications by an authorized administrator of UKnowledge. For more information, please contact UKnowledge@lsv.uky.edu. 


\section{Amylin as a Potential Link between Type 2 Diabetes and Alzheimer Disease}

\section{Digital Object Identifier (DOI)}

https://doi.org/10.1002/ana.25668

\section{Notes/Citation Information}

Published in Annals of Neurology, v. 87, issue 3.

(c) 2020 American Neurological Association

This is the pre-peer-reviewed version of the following article: Despa, F., Goldstein, L. B., \& Biessels, G. J. (2020). Amylin as a potential link between type 2 diabetes and Alzheimer disease. Annals of Neurology, 87(3), 486-486, which has been published in final form at https://doi.org/10.1002/ana.25668. This article may be used for non-commercial purposes in accordance with Wiley Terms and Conditions for Use of Self-Archived Versions. 
Published in final edited form as:

Ann Neurol. 2020 March ; 87(3): 486. doi:10.1002/ana.25668.

\title{
Amylin as a Potential Link between Type 2 Diabetes and Alzheimer Disease
}

\author{
Florin Despa, $\mathrm{PhD}^{1,2}$, Larry B. Goldstein, MD $^{2}$, Geert Jan Biessels, MD, PhD ${ }^{3}$ \\ ${ }^{1}$ Department of Pharmacology and Nutritional Sciences, University of Kentucky, Lexington, KY, \\ USA ${ }^{2}$ Department of Neurology, University of Kentucky, Lexington, KY, USA ${ }^{3}$ Department of \\ Neurology, University Medical Center Utrecht, Utrecht, The Netherlands
}

Martinez-Valbuena et al. ${ }^{1}$ provide histological evidence of amylin- $\beta$ amyloid (A $\beta$ ) and amylin-tau cross-seeding in both pancreatic and brain tissues, suggesting a possible connection in the pathogenesis of Alzheimer's disease (AD) and type 2 diabetes. They noted pancreatic amylin- $\mathrm{A} \beta$ and amylin-tau deposits in humans with $\mathrm{AD}$ in the absence of type- 2 diabetes, which the authors interpreted as potential evidence for a role of $\mathrm{A} \beta$ and tau tangle pathology in insulin resistance in these subjects. We suggest an alternative interpretation of this finding that we base on four key observations: 1 , pancreatic $\beta$-cells express and process both the $\mathrm{A} \beta$ protein precursor and tau mRNAs ${ }^{2}$ implying that amylin- $\mathrm{A} \beta$ and amylin-tau inclusions may originate from the pancreas; 2 , affected age-groups and clinical trajectories in type-2 diabetes and late-onset AD generally indicate that diabetes most commonly precedes $\mathrm{AD}$ and is associated with an acceleration of the transition from mild cognitive impairment to dementia; 3 , consistent with this observation and because rodent amylin is non-amyloidogenic, rodent AD models do not develop type-2 diabetes, whereas pancreatic expression of amyloid-forming human amylin in non-AD rats causes type-2 diabetes, brain amylin deposition and behavior deficits ${ }^{3}$; and 4 , the brain region involved in the central regulation of pancreatic $\beta$-cell function (i.e., the hypothalamus) ${ }^{4}$ is affected by $\mathrm{AD}$ pathology. Consequently, AD may impair central signaling pathways that regulate amylin secretion leading to pancreatic $\beta$-cell dysfunction and impaired clearance of amylin, $A \beta$ and tau. We therefore posit that the presence of mixed amylin-A $\beta$ or amylin-tau inclusions in the pancreatic $\beta$-cells of patients with AD may reflect an in situ stress response to comorbid endocrine dysfunction and amylin dyshomeostasis.

Martinez-Valbuena et al ${ }^{1}$ highlight the complex mechanisms underlying pancreatic $\beta$-cell dysfunction and linked amylin- $A \beta$ and amylin-tau pathology in type- 2 diabetes. Taken together with published evidence showing the presence of mixed amylin-A $\beta$ pathology in human $\mathrm{AD}^{5}$, these new data ${ }^{1}$ provide support for the hypothesis that overexpression and/or impaired clearance of amyloidogenic proteins (amylin, A $\beta$, tau) are critical pathological pathways in both type- 2 diabetes and $\mathrm{AD}$. Without excluding possible contributions of $\mathrm{A} \beta$ and tau tangle pathology to the development of type-2 diabetes, our alternative interpretation only serves to emphasize the need for in vivo studies that can further elucidate the temporal sequence of amylin- and $\mathrm{A} \beta$-mediated pathological events involving type- 2 diabetes and AD. 


\section{References}

1. Martinez-Valbuena I, Valenti-Azcarate R, Amat-Villegas I et al. Amylin as a potential link between type 2 diabetes and Alzheimer Disease. Ann Neurol 2019;10.1002/ana.25570

2. Miklossy J, Qing H, Radenovic A et al. Beta amyloid and hyperphosphorylated tau deposits in the pancreas in type 2 diabetes. Neurobiol Aging 2010;31:1503-1515. [PubMed: 18950899]

3. Ly H, Verma N, Wu F et al. Brain microvascular injury and white matter disease provoked by diabetes-associated hyperamylinemia. Ann. Neurol 2017;82:208-222. [PubMed: 28696548]

4. Rosario W, Singh I, Wautlet A et al. The brain-to-pancreatic islet neuronal map reveals differential glucose regulation from distinct hypothalamic regions. Diabetes 2016; 65:2711-2723. [PubMed: 27207534]

5. Jackson K, Barisone GA, Diaz E et al. Amylin deposition in the brain: A second amyloid in Alzheimer disease? Ann Neurol. 2013;74:517-26. [PubMed: 23794448] 